\title{
Androgen receptors in early and castration resistant prostate cancer: friend or foe?
}

\author{
Vassiliki Pelekanou, ${ }^{1,2^{*}}$ George Notas, ${ }^{1 *}$ Efstathios N. Stathopoulos, ${ }^{2}$ Elias Castanas, ${ }^{1}$ \\ Marilena Kampa ${ }^{1}$
}

Departments of ${ }^{1}$ Experimental Endocrinology and ${ }^{2}$ Pathology, University of Crete, School of Medicine, Heraklion, Crete, Greece

*Authors have equally contributed

\section{INTRODUCTION}

Prostate cancer is one of the most common malignancies and causes of death among men in western societies. It has thus attracted the interest of the scientific community, which has resulted in great improvements in survival rates in recent years. As early as the 1940s, Huggins and Hodges first demonstrated that prostate cancer is androgen dependent, ${ }^{1}$ initiating the wide use of androgen deprivation as an adjuvant therapy. Similarly, during the late 70's the clinical significance of the prostate specific antigen (PSA) was shown, resulting in early disease detection and monitoring of its evolution. Despite these significant achievements, a major persistent therapeutic challenge remains in prostate cancer: the discovery of new treatment strategies for the disease when hormone resistance sooner or later develops

Key words: Androgen receptor, Cancer, CRPC, Nuclear-extranuclear actions, Receptor isoforms, Therapy

\footnotetext{
Address for correspondence:

Dr Marilena Kampa, University of Crete, School of Medicine, Laboratory of Experimental Endocrinology, P.O. Box 2208, Heraklion, 71110, Crete, Greece, Tel.: +30 2810 394580, -15, Fax: +30 2810 394581, e-mail: kampa@med.uoc.gr Received 14-08-2012, Accepted 28-02-2013
}

(castration resistant prostate cancer, CRPC). This presupposes a better understanding of the mechanisms involved in androgens actions in prostate cancer. In the following sections we will present an overview of our knowledge accumulated to date on the role of androgen receptor in prostate cancer. Its different modes of action and their therapeutic value will be analyzed.

\section{ANDROGEN RECEPTOR STRUCTURE, CELLULAR LOCALIZATION AND FUNCTION}

Androgen receptor (AR) is a 919 amino acid protein with a mass of $110 \mathrm{kDa}$ and, as a member of the nuclear receptor superfamily, it contains four distinct domains $^{2}$ (Figure 1): an N-terminal domain (NTD, aa 1-537), a highly conserved DNA binding domain (DBD, aa 538-625), a hinge region (aa 626-669) and a ligand binding domain (LBD, aa 670-919). The short hinge region contains one of the four signals for the nuclear transport of AR (nuclear localization signal, NLS) which is important for AR-mediated transcriptional biological responses. The other three NLSs reside in the ligand binding domain, the DNA binding domain and the N-terminal domain. ${ }^{3}$ The latter can activate transcription independently of ligand binding and contains transcriptional activation functions (AF) -1 and -5. A third transcriptional activation function, $\mathrm{AF}-2$, is located in the ligand binding domain. All AFs can interact with LxxLL-containing 
co-regulators, even though AF-2 has a low affinity. ${ }^{4}$ Interestingly, the AF- 2 of $\mathrm{AR}$, in contrast to other nuclear receptors, primarily interacts with coactivators that contain FxxLF motifs. These motifs are also present in the NTD of the receptor and therefore NTD and co-regulatory proteins compete for AF-2 binding. The importance of this competition is unknown. ${ }^{4,5}$ Another motif at the NTD that is involved in the NTD and LBD interaction is ${ }_{23} \mathrm{FQNLF}_{27}$ at position $23 .{ }^{6,7}$ This interaction is very strong, so that any deletion or mutation that involves this motif abrogates NTD-LBD interaction.?

AR can exist in a number of variants (Figure 1). The first that was described is AR45 which lacks the entire NTD encoded by exon 1 ; it contains instead a seven amino acid $\mathrm{N}$-terminal extension ${ }^{8}$ and has a molecular weight of $45 \mathrm{kDa}$. AR45 has an inhibitory effect on AR function and its presence inhibits the proliferation of the hormone-sensitive LNCaP hu- man prostate cancer cells. ${ }^{8}$ Moreover, variants with changes at the carboxyl end of the protein have been found, such as a number of truncated AR proteins (ARV567ES, ARV1, ARV7) $)^{9,10,12}$ with intact NTD and DBD but a short variant-specific peptide replacing the functional LBD. In contrast to AR45, ARV567ES functions as a constitutively active receptor, increases AR expression and enhances its transcriptional activity. Both ARV7 and ARV567ES enhance cell survival in an androgen depleted environment and are up-regulated in CRPC. ${ }^{10-12}$ Another splice variant is AR23 that has an insertion of 23 amino acids at the DNA binding domain, which exhibit only cytoplasmic activity altering the activity of transcription factors such as NF- $x$ B and AP- $1 .{ }^{13}$ Finally, another splice variant, AR8, has recently been demonstrated, which lacks the DBD additionally to the NTD and is primarily localized at the plasma membrane. ${ }^{14}$ This variant has been shown to cooperate with classical AR and EGFR by increasing AR tyrosine phospho-
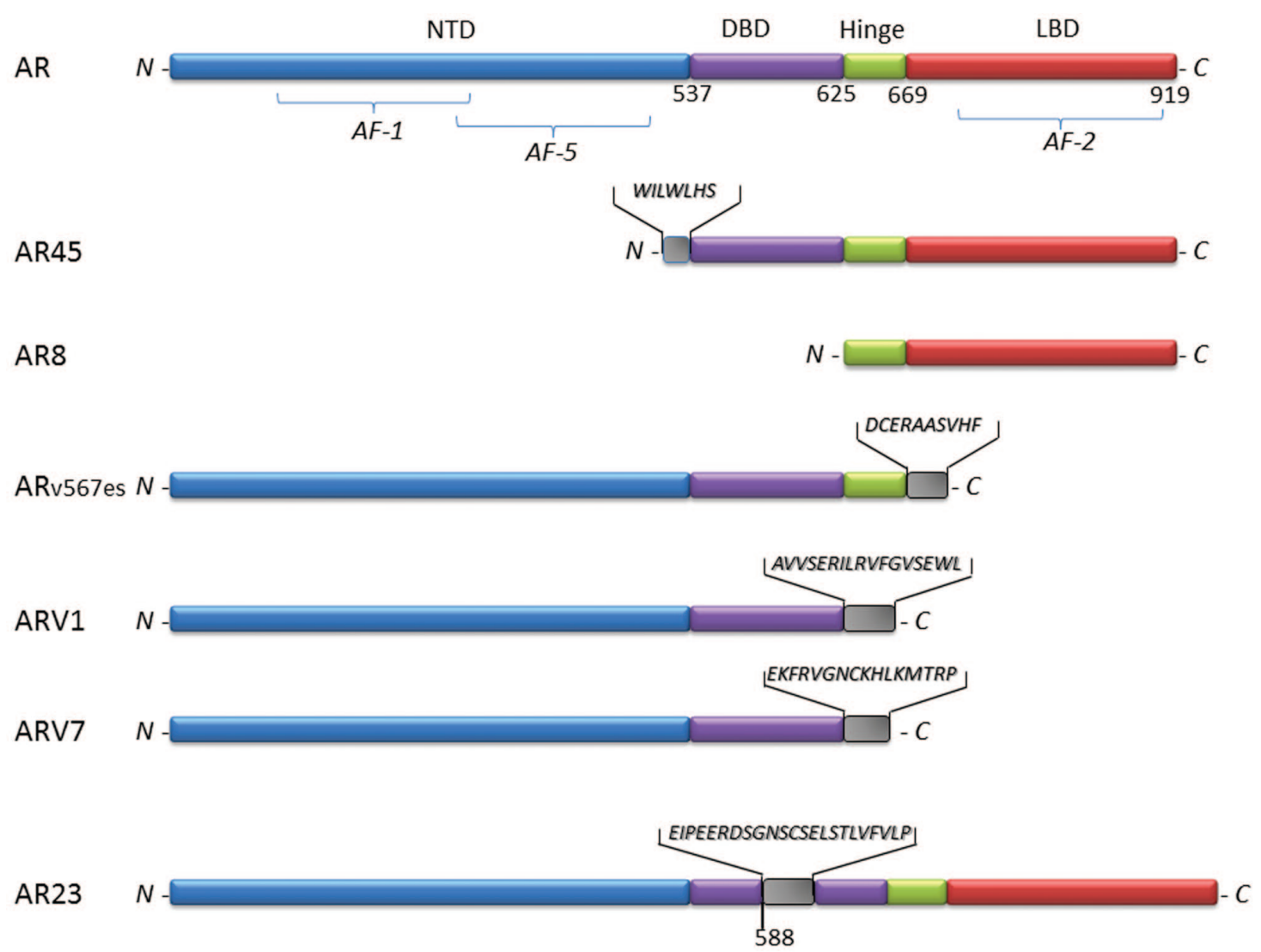

Figure 1. Structural domains of AR and its more important isoforms and splice variants. NTD: N-terminal domain, DBD: DNA binding domain, LBD: ligand binding domain, AF: transcriptional activation function. 
rylation, leading to enhanced androgen and growth factor response in prostate cancer cells. ${ }^{14}$ All these variants have been implicated in androgen-insensitive prostate cancer cell growth, which will be discussed in detail below.

AR primarily resides in the cytoplasm as a dimmer and a complex with heat shock (such as HSP-90) and other chaperone proteins, which are tethered to cytoskeletal proteins, such as filamin A that interacts directly with AR and facilitates AR translocation to the nucleus. ${ }^{20}$ Upon androgen binding, the complex is disrupted and the liganded AR as a dimmer becomes phosphorylated, along with several co-regulators, and enters the nucleus where it interacts with the DNA at certain androgen response elements (AREs) affecting the transcription of a number of genes, such as PSA. ${ }^{21,22}$ The DBD domains of the receptor dimmer recognize hexameric binding sites (organized in inverted repeats) separated by three nucleotides. The classical consensus sequence for ARE is 5'-TGTTCT-3' and is also the same for glucocorticoid, mineralocorticoid and progestagen receptors. ${ }^{23,24}$ However, for AR there are also selective AREs which seem to be partial direct repeats of the above motif and to bind the DBD of AR but not that of the glucocorticoid receptor. ${ }^{25}$

Additionally, AR can be trans-activated by growth factors (i.e. EGF, IGF, KGF) and cytokine (i.e. IL6) signaling. Indeed, AR has been described as the target of several MAPKs such as Akt/PKB, PKA, PKC (Figure 2). This cross-talk of AR with growth factor signaling events is extensively studied since it has been associated with metastatic and hormone resistant disease state (see below and Reference ${ }^{26}$ for a review).

Finally, during the last decade membrane initiated androgen actions have been described in several cell

Table 1. Tissues and cells where the different AR isoforms and splice variants have been found to be expressed

\begin{tabular}{|c|c|c|c|c|c|c|}
\hline & \multicolumn{6}{|c|}{ AR isoform/variant } \\
\hline & AR45 & AR8 & ARv567es & ARV1 & ARV7 & AR23 \\
\hline $\begin{array}{l}\text { Tissues, } \\
\text { cells and } \\
\text { cell lines } \\
\text { expressed }\end{array}$ & $\begin{array}{l}\text { Prostate, Testis, } \\
\text { Uterus, Breast, } \\
\text { Heart, Lung, } \\
\text { Trachea, Liver, } \\
\text { Kidney and Muscle } \\
\text { LNCaP cells, } \\
\text { Cardiomyocytes, } \\
\text { HepG2 cells, and } \\
\text { hepatocellular } \\
\text { carcinoma cells }\end{array}$ & $\begin{array}{l}\text { Benign and } \\
\text { malignant } \\
\text { prostate cells, } \\
\text { LNCaP, C4-2 } \\
\text { and C4-2B } \\
\text { cells }\end{array}$ & $\begin{array}{l}\text { Normal and } \\
\text { malignant } \\
\text { prostate } \\
\text { epithelial cells, } \\
\text { LuCap } \\
\text { xenografts }\end{array}$ & $\begin{array}{l}\text { Prostate } \\
\text { cancer cells } \\
\text { from CRPC } \\
\text { patients } \\
\text { Primary } \\
\text { tumors and } \\
\text { bone } \\
\text { metastases }\end{array}$ & $\begin{array}{l}\text { Normal (low } \\
\text { levels) and } \\
\text { malignant } \\
\text { (higher levels) } \\
\text { prostate } \\
\text { epithelial cells, } \\
\text { prostate } \\
\text { cancer cells } \\
\text { from CRPC } \\
\text { models and } \\
\text { CRPC patients, } \\
\text { VCaP and Myc- } \\
\text { CaP cells, } \\
\text { LuCap } \\
\text { xenografts }\end{array}$ & $\begin{array}{l}\text { Metastatic } \\
\text { prostate } \\
\text { cancer after } \\
\text { anti-androgen } \\
\text { treatment }\end{array}$ \\
\hline Function & $\begin{array}{l}\text { Inhibits AR } \\
\text { function by the } \\
\text { formation of } \\
\text { AR-AR45 } \\
\text { heterodimers }\end{array}$ & \begin{tabular}{|l} 
Primarily \\
localized at \\
the plasma \\
membrane Its \\
over- \\
expression \\
promotes \\
association of \\
Src and AR \\
with EGF \\
receptor
\end{tabular} & $\begin{array}{l}\text { Constitutively } \\
\text { active } \\
\text { Increases the } \\
\text { expression of } \\
\text { AR }\end{array}$ & $\begin{array}{l}\text { Constitutive } \\
\text { and ligand } \\
\text { independent } \\
\text { activation } \\
\text { Confers } \\
\text { castration } \\
\text { resistant } \\
\text { growth }\end{array}$ & $\begin{array}{l}\text { Constitutive } \\
\text { and ligand } \\
\text { independent } \\
\text { activation } \\
\text { Confers } \\
\text { castration } \\
\text { resistant } \\
\text { growth }\end{array}$ & $\begin{array}{l}\text { No nuclear } \\
\text { localization } \\
\text { and activation } \\
\text { of androgen } \\
\text { responsive } \\
\text { reporters } \\
\text { Increases AR } \\
\text { activation }\end{array}$ \\
\hline References & $8,15,16$ & 14 & 12,10 & $17,9,18$ & 11,12 & 13,19 \\
\hline
\end{tabular}




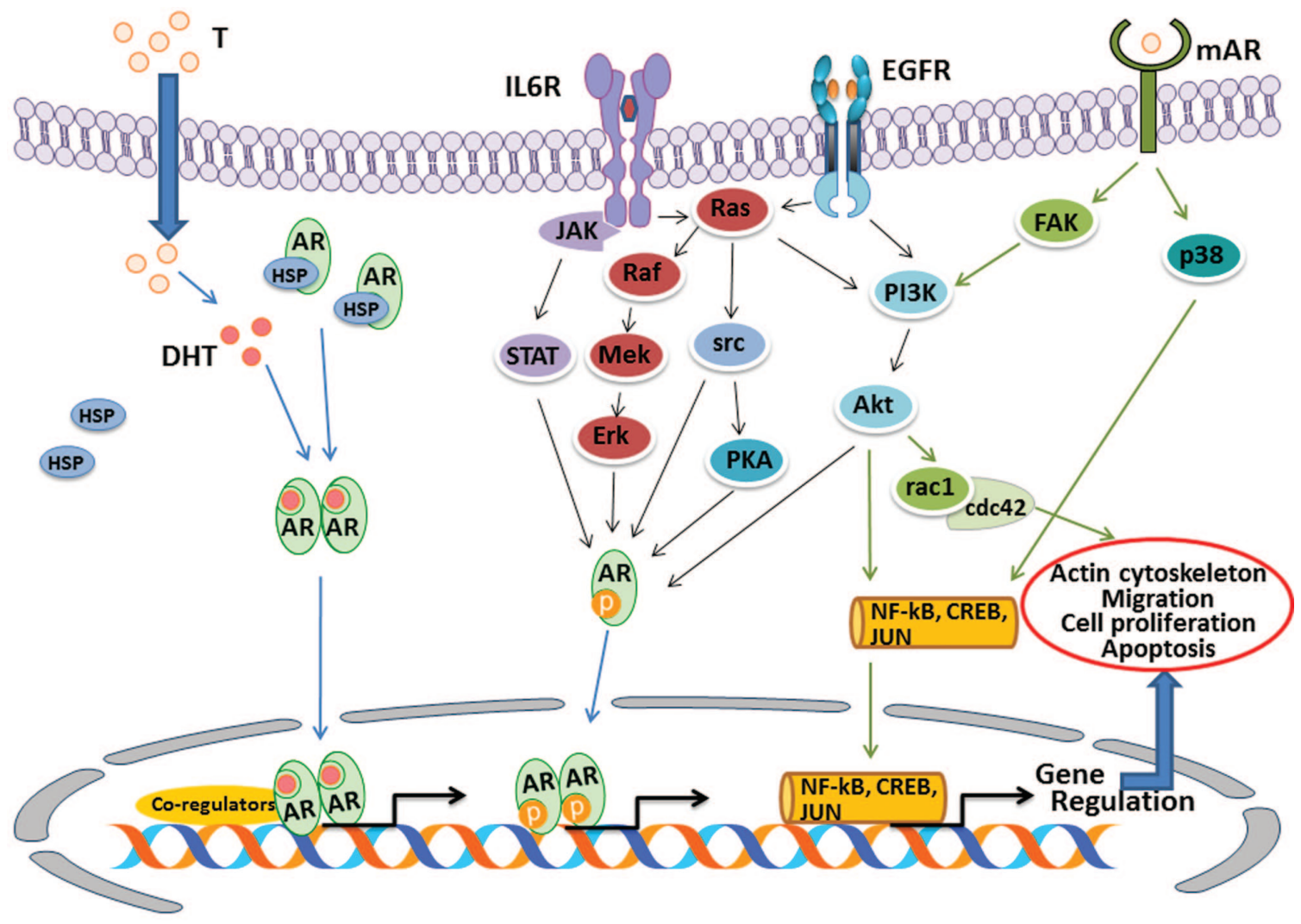

Figure 2. Mechanisms of action of AR. T: Testosterone, DHT: Dihydrotestosterone, IL6R: Interleukin 6 Receptor, EGFR: Epidermal Growth Factor, mAR: membrane AR, HSP: Heat Shock Protein, JAK: Janus Kinase, STAT: Signal Transducer and Activator of Transcription, PKA: Protein kinase A, FAK: Focal adhesion kinase, PI3K: Phosphoinositide-3 kinase, cdc42: Cell division control protein 42 homolog, NF-kB: Nuclear Factor-Kappa B, CREB: cAMP response element-binding protein.

types and are involved in the development, growth, survival and/or function of cells in different organ systems (osteoblasts, neurons, cardiomyocytes, endothelial, vascular smooth muscle, myometrial, sertolli, spermatozoa, T lymphocytes, breast), ${ }^{27-33}$ including prostate cancer. ${ }^{34-37}$ In prostate cells, we have shown that androgens bind to specific membrane molecules, while in the majority of cases these molecules are not recognized by antibodies raised against different parts of the AR. We have reported for the first time the presence of androgen membrane binding sites in prostate cancer cell lines, patients' isolated cells and paraffin embedded tissue specimens..$^{34,36,37}$ We have additionally shown that their activation triggers different signaling cascades (Figure 2), induces rapid ion $\left(\mathrm{Ca}^{2+}\right)$ movements and cytoskeletal rearrangement and modulates secretion of androgen related molecules. ${ }^{38-40}$ At a second stage, these rapid actions lead to specific transcriptional effects ${ }^{41}$ and activation of molecules, resulting in apoptosis. ${ }^{37}$ These effects have also been observed in vivo in human tumor xenografts in nude mice..$^{42}$ Moreover, membrane acting agonists enhanced the antitumor effect of paclitaxe ${ }^{38}$ through an additive effect on the cytoskeleton.

Even though specific membrane androgen binding sites have been demonstrated, their nature has not yet been elucidated. The anchorage of the classical $\mathrm{AR}$ at the membrane has been suggested, as has also been described for ER $\alpha$ involving caveolin-1 and palmitoylation of the receptor at cysteine 447 , since AR contains a comparable 9 amino acid motif. ${ }^{43}$ However, evidence exists of the presence of a different molecule(s) than the classical AR: a) membrane initiated actions can be triggered by androgens conjugated to macromolecules (BSA) that render them impermeable to cell membrane; b) these conjugated androgens can induce a differential transcriptional effect compared to unconjugated ones, ${ }^{41} \mathrm{c}$ ) classical 
AR antagonists like cyproterone acetate or flutamide do not inhibit these actions, ${ }^{37}$ which d) have also been observed in cells (DU-145) ${ }^{37}$ showing an androgen independent growth due to absence or, as recently demonstrated, expression of low levels of classical AR. ${ }^{44}$ Therefore, (a) new receptor element(s) that binds androgens is(are) present at the membrane and/or it is an AR isoform(s) that has previously been described as existing in prostate cancer cells as the result of an alternative splicing (see above).

\section{ANDROGEN RECEPTOR AS A TARGET IN PROSTATE CANCER THERAPY}

In prostate cancer, luminal cells that constitute the great majority of cells depend for their survival on androgens, whose actions are primarily mediated through AR. Consequently, these cells express high levels of AR, in contrast to the more undifferentiated basal layer cells that are androgen independent and express low levels of AR. In fact, AR in basal epithelial cells has been shown to play a suppressive role in their proliferation. ${ }^{45}$ Stromal cells also express AR but at lower levels in areas surrounding cancerous tissue. In contrast to epithelial cells, the role of stromal AR in prostate carcinogenesis is controversial. It has been shown that AR expressing stromal cells suppressed prostate cancer growth in vitro and in vivo, suggesting an opposite role for AR in the stromal layer which can influence prostate cancer cell growth. ${ }^{46}$ On the other hand, two recent studies demonstrated that loss of stromal AR leads to suppressed prostate carcinogenesis by suppressing epithelial growth and tumor-promoting environment by modulating proinflammatory cytokines. ${ }^{47,48}$ However, the extensively studied androgen dependence of prostate epithelial cancer cells remains the basis for the widely used hormonal therapies.

The better understanding of androgen synthesis and mode of action led to the development of a number of androgen suppression approaches, ${ }^{49}$ which are widely utilized for advanced/metastatic prostate cancer, as recommended by the guidelines of the European Association of Urology.$^{50}$ Moreover, they are also used in earlier stages of prostate cancer alone, or most often as neo-adjuvant/adjuvant therapy after radical prostatectomy and/or radiotherapy. ${ }^{51}$
These therapies include three major categories: (i) surgical orchiectomy, estrogens, LHRH agonists or antagonists that reduce serum testosterone levels, (ii) 5- $\alpha$-reductase inhibitors blocking the synthesis of the most active intracellular androgen, DHT and (iii) anti-androgens that block the action of androgens with AR being target. The most widely used anti-androgens are the non-steroidals bicalutamide, flutamide and nilutamide and the steroidal cyproterone acetate, which compete with androgens for AR binding and therefore inhibit their action as well as reducing their expression. Non-steroidal anti-androgens have the advantage of not having any steroidal side effect.

When applied, androgen deprivation initially induces apoptosis of prostate cancer cells, resulting in a significant tumor regression. However, the majority of tumors become resistant at a later stage ${ }^{52}$ and patients develop a hormone refractory disease, also known as CRPC. Several mechanisms have been described so far for this disease progression characterized by tumor cell survival in an androgen-depleted environment. These include:

a) Altered expression of steroidogenesis enzymes by cancer cells, leading to increased androgen levels within the tumor environment. ${ }^{53}$ Increased expression of enzymes such as CYP19A1, SRD5A2, HSD3B2, HSD17B3, AKR1C3, UGT2B15, in combination with the loss of enzymes mediating DHT catabolism, such as AKR1C1, AKR1C2, contributing to cancer cell survival in an androgen deprived environment. ${ }^{54,55}$

b) Overexpression of AR due to DNA amplification and response to low levels of androgens. ${ }^{56}$ More than $60 \%$ of CRPC metastasis has been found to overexpress $\mathrm{AR}^{57,58}$ and approximately in one third of these cases the mechanism of this overexpression is the amplification of the AR locus. ${ }^{57,59}$ Other mechanisms may include increased transcription (increased AR expression has been described due to E2F activity in retinoblastoma deficient tumors ${ }^{60}$ ) and/or increased mRNA stability.

c) AR gene mutations that result in altered ligand specificity and account for only $10 \%$ of the patients that progress to CRPC. ${ }^{61,62} \mathrm{AR}$ mutations in the hinge region and LBD are responsible for increased affinity to DHT, mutations at the N-terminal of 
the LBD broaden AR specificity for other ligands such as glucocorticoids and progesterone and mutations within the AF-2 region convert antagonists to antagonists. ${ }^{63,64}$

d) Activation of signaling pathways that can induce AR activity (Figure 2) even independently of the presence of androgens. ${ }^{65}$ Several signaling pathways have been described as enhancing AR activity, indirectly via the phosphorylation of several transcription factors or directly by phosphorylating AR itself. This activation can enhance AR activity, at very low levels or in the absence of androgens, following androgen deprivation therapy. The pathways implicated so far are that of EGF, IGF, IL6, Wnt and the Ras-Raf-MAP kinase pathway. ${ }^{65-69}$ EGF treatment of LNCaP cells in the absence of androgens induces AR phosphorylation (tyr267,-534). ${ }^{70}$ Interestingly, wnt3A protein and beta catenin can recruit AR to the promoter regions of several genes (such as myc, cyclin D1 and PSA). ${ }^{67}$ Additionally, activation of Cdk1, PKA, PI3K/ Akt and Stat 3 may enhance AR transcriptional responses. ${ }^{26} \mathrm{Cdk} 1$ phosphorylates $\mathrm{AR}$ at serine 81 and stabilizes the receptor, ${ }^{71}$ activation of the $\mathrm{PI} 3 \mathrm{~K} /$ Akt pathway results in AR phosphorylation and promotion of cell survival ${ }^{72}$ and Stat 3 can form a heterologous complex with AR (stat3-AR) by interacting directly with amino acids 234-558 in the NTD of AR..$^{73}$ Therefore, whenever stat 3 is activated, for example as a response to EGF and IL6, then AR is activated. ${ }^{74}$

e) Induction of pathways that give cells the ability to overcome androgen deprivation apoptosis. Indeed androgen ablation augments the expression of the anti-apoptotic oncogene bcl-2. ${ }^{75}$

f) Emergence of $A R$ isoforms with different activity and regulation by the ligand ${ }^{12}$ (see above and Table 1 for details).

g) Presence of undifferentiated AR negative cancer stem cells that can survive in an androgen-depleted environment. ${ }^{76}$ Cancer stem cell theory states that prostate stem cells that are present within the tumor can differentiate to transient amplifying cells which give rise to committed basal and later differentiate to luminal cells. Interestingly, in the majority of cancer stem cell phenotypes (no consensus phenotype has yet been achieved) ARs are undetectable; cells are therefore not dependent on androgen for survival and thus may escape androgen deprivation apoptosis, ${ }^{76}$ leading to the progression of the disease.

All these mechanisms suggest that an important distinction should be made between serum androgen levels and androgenic action at the cellular level and point to the need for the development of markers reflecting the presence of active androgens at the tissue level. ${ }^{77}$

When CRPC has developed, the available therapeutic choices are rather few and survival is limited to $9-13$ months for metastatic CRPC. ${ }^{78}$ Docetaxel chemotherapy has FDA approval since 2004, while during the last three years cabazitaxel (a semisynthetic taxane), sipuleucel-T (an immunotherapy against prostatic acid phosphatase), denosumab (monoclonal antibody against RANKL that prevents osteoclast mediated bone destruction) and abiraterone (an inhibitor of CYP17, involved in adrenal steroidosynthesis) have also been approved. ${ }^{79}$ In spite of these advances, treatment of CRPC still comprises the major therapeutic challenge in prostate cancer.

Recently, a new and more potent AR antagonist, MDV3100, has been reported. ${ }^{80,81}$ It binds to AR with greater affinity and blocks AR translocation to the nucleus, co-activator and DNA binding and has no agonistic activity. It is at present in phase III trials for the treatment of late stage metastatic disease. In the category of small molecule antagonists for AR, there are three other agents undergoing evaluation in early clinical studies (phase I/II). The first is ARN509 which has an in vitro activity similar to MDV3100 but which is enhanced in vivo. ${ }^{80,82}$ It impairs nuclear AR localization and DNA binding and it is a potent inhibitor of tumor growth with greater efficacy, thus reducing the seizure risk observed with high doses of MDV3100, via antagonism of the central nervous system (CNS)-based $\mathrm{GABA}_{\mathrm{A}}$ receptor. AZD3514 is a selective AR down-regulator. It binds to the LBD of AR, inhibits AR translocation to the nucleus and transcription, but also reduces AR protein levels, thus differentiating it from other AR antagonists such as bicalutamide and MDV3100. Thirdly, Galeterone (TOK-001) is a dual molecule that inhibits CYP17 
but is also an AR antagonist and causes receptor down-regulation. It was found to inhibit hormone resistant prostate cancer cell lines that are no longer sensitive to bicalutamide and prostate cancer xenograft models. ${ }^{83,84}$

Additionally, two other classes of agents with anti-androgenic action are quite promising for the treatment of CRPC and their safety and efficacy is either under assessment or will be in the near future. They include compounds that interfere with the AR transcriptional complex and molecules that target AR but in a LBD independent manner. In the first class, an Hsp27-targeting locked antisense (OGX427 ) is a possible candidate. Ligand activated AR phosphorylates Hsp27 which displaces Hsp90 from the complex with AR and enhances AR stability and transcriptional activity. Knocking down Hsp27 with OGX-427 results in increased AR degradation, AR transcriptional activity and increased apoptosis, as shown in LNCaP cells. ${ }^{85}$ At the moment, OGX-427 is undergoing evaluation together with prednisone in a phase II trial. The second class contains molecules that can act as non-competitive inhibitors by targeting $\mathrm{AR}$ at a different site other than the LBD. This need arose through the fact that, as described above, AR can exist in several mutated shorter forms lacking part of or the entire LBD and exhibits constitutive activity. Therefore, for CRPC where AR mutants exist, NTD has been a possible target. ${ }^{86}$ A representative compound of this class is a small molecule named EPI-001, identified by Andersen and colleagues by screening extracts from marine sponge that inhibits AR activity, regardless of the presence of a ligand. It interacts with AF-1 in NTD, inhibits N terminal and $\mathrm{C}$ terminal interaction and blocks protein-protein interaction with $\mathrm{AR}$ and $\mathrm{AR}$ interaction with AREs. As a consequence, it blocked androgen induced proliferation and tumor growth in CRPC xenografts. ${ }^{87}$

Finally, it should be noted that due to the existence of a cross-talk of AR with growth factor signaling events, a second line hormonal treatment such as anti-survival factor treatment has been utilized with biochemical and/or clinical benefits in a large portion of CRPC patients. This includes the use of dexamethasone and/or somatostatin analogs along with androgen ablation and anti-androgen therapy. ${ }^{88,89}$

\section{POTENTIAL ROLE OF MEMBRANE INITIATED ANDROGEN ACTIONS IN ADVANCED PROSTATE CANCER THERAPY}

Our knowledge on membrane initiated androgen actions in prostate cancer so far is very limited. However, the first evidence that we have from our work in the field during the last decade points to a significant role for membrane AR that should definitely be further exploited. In fact, we demonstrated that membrane ARs are more frequently expressed in cancer cells than in $\mathrm{BPH}$ or normal prostate cells. ${ }^{35}$ Interestingly, we detected mAR in a number of cell lines that are characterized as androgen-insensitive ${ }^{37}$ and, after developing a fluorescence detection method in paraffin embedded tissues, we reported that their expression increased with the Gleason score, pointing out that they are preferentially expressed in more undifferentiated disease. ${ }^{36}$ Taking into consideration the pro-apoptotic effect of $\mathrm{mAR}$ activation, this finding is particularly important. Indeed, $\mathrm{mAR}$ presence at the more advanced stages of the disease, when cancer cells are unresponsive to androgen deprivation therapy, could be a novel therapeutic target, since their activation can lead to tumor regression.

In fact, over the last 70 years during which a connection between androgens and prostate cancer has been established, there have been studies demonstrating that patients with metastatic hormone refractory prostate cancer at a terminal stage showed great improvement after treatment with testosterone. This type of treatment with high doses of testosterone, known as testosterone replacement therapy (TRT), has also been utilized by some clinicians for hypogonadism after initial cancer therapy, including primary androgen-deprivation therapy (ADT). Symptoms of hypogonadism were improved but there is reluctance to administer this kind of therapy due to a possible risk of stimulating prostate cancer growth. However, as described by Leibowitz and colleagues, $40 \%$ of patients on TRT responded well and had no significant PSA increase or clinical/symptomatic disease progression. ${ }^{90}$ In 2009, two phase I trials of exogenously administered high dose of testosterone in castration-resistant prostate cancer were published..$^{91,92}$ Only in the second study, in which testosterone levels were raised to an average of $589 \mathrm{ng} / \mathrm{dL}$ in 7/12 recruited patients, was a significant decrease in PSA levels (7.9\%-49\%) ob- 
served. ${ }^{92}$ However, it should be noted that the effect of high dose testosterone on PSA most likely cannot be attributed to a direct non-genomic action on PSA but to its extranuclear effect, which has been found to induce apoptotic death of prostate cancer cells. Finally, at the moment there is an ongoing phase II trial for exogenous testosterone plus Dutasteride (a $5-\alpha$ reductase inhibitor that inhibits the conversion of testosterone to its more active form DHT) for the treatment of castrate metastatic prostate cancer that will be completed in 2013. The difference between the two trials and the fact that some patients respond well to TRT while others do not indicates that new tools are required for the better selection of those patients that will respond to such a treatment.

So, how might androgen influence CRPC regression? A hypothesis advanced by our group in recent years is that this may occur through membrane androgen sites. Indeed, impermeable androgen (acting exclusively on these membrane sites), ${ }^{37}$ as well as micromolecular agonists of membrane ARs (mARs), ${ }^{93}$ induce regression of tumor xenografts, initiated by AR-negative prostate cancer cells, mimicking CRPC. In this respect, $\mathrm{mAR}$ presence may represent a pos- sible marker for a positive TRT response as well as a new target for the development of specific therapeutic agonists. Furthermore, the presence of mAR in high grade tumors ${ }^{36}$ and mesenchymal stem cells (unpublished observations) are candidates for such a potential role. Finally, we have recently tested prostate cancer specimens of a small number of patients who responded to TRT in comparison to non-responders for $\mathrm{mAR}$ expression (unpublished data). Interestingly, those patients who exhibited high levels of mAR (Figure 3) were those that responded well to TRT, with PSA below $0.2 \mathrm{ng} / \mathrm{ml}$. As expected, non-responders showed low or no expression of mAR.

\section{CONCLUDING REMARKS}

The continuous progress being made in the field of androgen action and prostate cancer has led to a number of therapeutic advances, lowering mortality rates and improving the quality of life of thousands of men worldwide. ${ }^{94,95}$ Since its identification, AR has been one of the main therapeutic targets and the use of anti-androgens is still the treatment choice for early and advanced disease. ${ }^{96}$

$\mathrm{AR}$ is expressed in the great majority of prostate

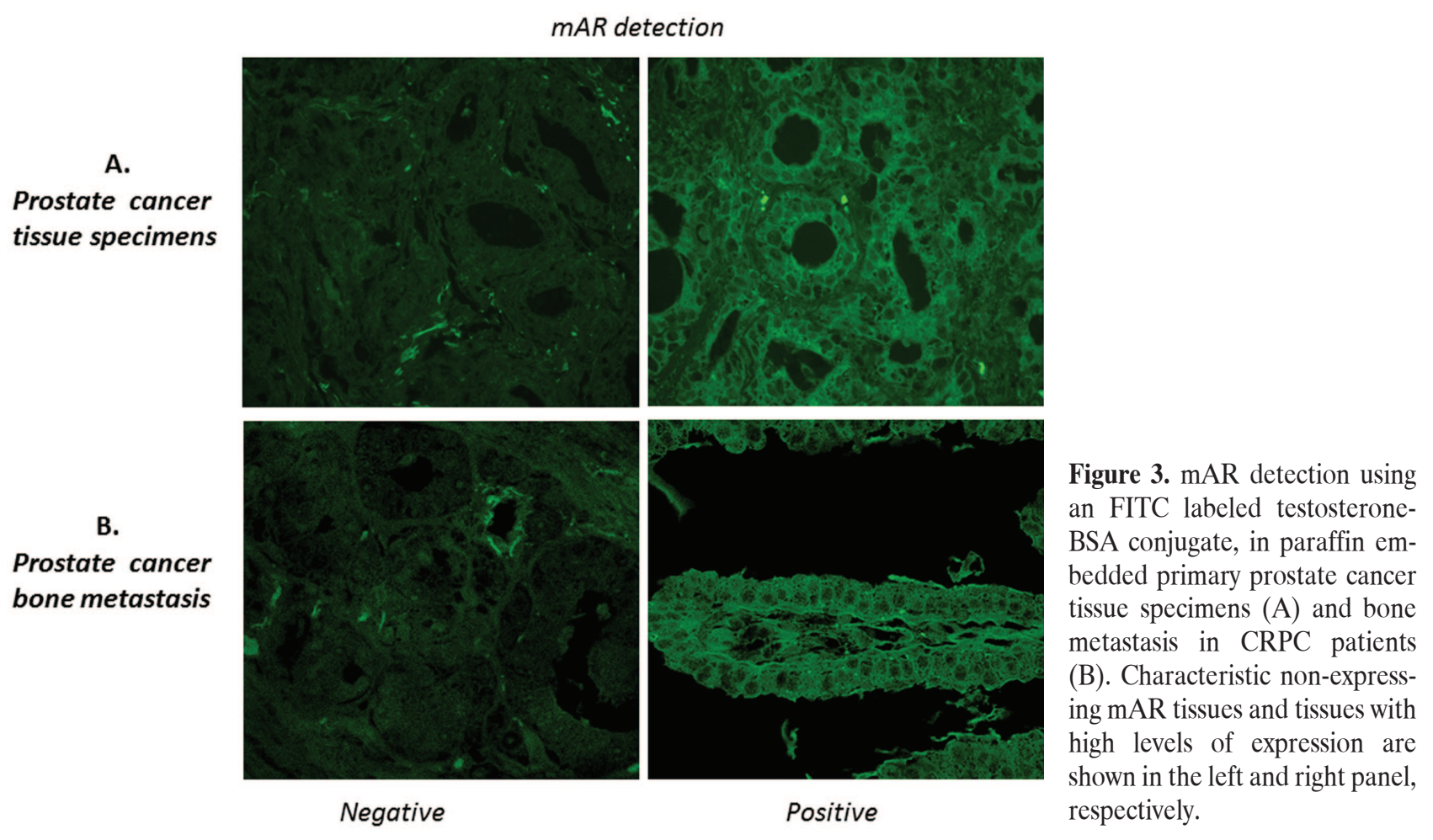


cancer cases,${ }^{97}$ while so far no correlation between its expression and Gleason score, node involvement, metastasis stage, pre-treatment PSA levels, prognosis or response to therapy has been established, even though different expression levels have been observed. ${ }^{97}$ As a consequence, AR is not routinely assayed in prostate cancer biopsies, as is the standard practice for estrogen receptors in breast cancer. AR is still present even when the disease becomes unresponsive to standard hormone deprivation therapies and a more aggressive CRPC phenotype emerges. Possibly, (a) different mutated hyperactive form(s) may exist or emerge, trans-activated by growth factors, in an androgen independent manner and/or is/ are located in a different cell compartment, such as the plasma membrane, initiating specific signaling cascades. As our group has previously reported, mAR exhibits an inhibitory action on cell growth that could be exploited therapeutically. In addition, we must not forget that AR can also be found in the stromal compartment of the tumor where primary evidence (stromal AR is less studied) indicates that stromal $\mathrm{AR}$ is associated with cancer progression. ${ }^{46}$

Therefore, more work is required in order to decipher the role of AR isoforms and/or membrane AR at the different stages of prostate cancer and within different cell populations other than the luminal cells, such as stromal and cancer stem cells. New molecules must be identified with longer duration and greater efficacy in CRPC that will differentially activate or antagonize specific isoforms. In parallel, it is essential to identify new biomarkers for therapy selection and prediction of patient's response. Novel membrane AR molecules and their agonists may represent such a target, as demonstrated above.

\section{REFERENCES}

1. Huggins C, Hodges CV, 2002 Studies on prostatic cancer: I. The effect of castration, of estrogen and of androgen injection on serum phosphatases in metastatic carcinoma of the prostate. 1941. J Urol 168: 9-12.

2. Claessens F, Denayer S, Van Tilborgh N, Kerkhofs S, Helsen C, Haelens A, 2008 Diverse roles of androgen receptor (AR) domains in AR-mediated signaling. Nucl Recept Signal 6: e008.

3. Kaku N, Matsuda K, Tsujimura A, Kawata M, 2008 Characterization of nuclear import of the domain-specific androgen receptor in association with the importin al- pha/beta and Ran-guanosine 5'-triphosphate systems. Endocrinology 149: 3960-3969.

4. Dubbink HJ, Hersmus R, Verma CS, et al, 2004 Distinct recognition modes of FXXLF and LXXLL motifs by the androgen receptor. Mol Endocrinol 18: 2132-2150

5. He B, Kemppainen JA, Wilson EM 2000 FXXLF and WXXLF sequences mediate the NH2-terminal interaction with the ligand binding domain of the androgen receptor. J Biol Chem 275: 22986-22994.

6. Berrevoets CA, Doesburg P, Steketee K, Trapman J, Brinkmann AO, 1998 Functional interactions of the AF-2 activation domain core region of the human androgen receptor with the amino-terminal domain and with the transcriptional coactivator TIF2 (transcriptional intermediary factor2). Mol Endocrinol 12: 1172-1183.

7. He B, Gampe RT, Jr, Kole AJ, et al, 2004 Structural basis for androgen receptor interdomain and coactivator interactions suggests a transition in nuclear receptor activation function dominance. Mol Cell 16: 425-438.

8. Ahrens-Fath I, Politz O, Geserick C, Haendler B 2005 Androgen receptor function is modulated by the tissuespecific AR45 variant. FEBS J 272: 74-84.

9. Hu R, Dunn TA, Wei S, et al. 2009 Ligand-independent androgen receptor variants derived from splicing of cryptic exons signify hormone-refractory prostate cancer. Cancer Res 69: 16-22.

10. Sun S, Sprenger CC, Vessella RL, et al, 2010 Castration resistance in human prostate cancer is conferred by a frequently occurring androgen receptor splice variant. J Clin Invest 120: 2715-2730.

11. Watson PA, Chen YF, Balbas MD, et al, 2010 Constitutively active androgen receptor splice variants expressed in castration-resistant prostate cancer require full-length androgen receptor. Proc Natl Acad Sci U S A 107: 16759-16765.

12. Hu R, Lu C, Mostaghel EA, et al, 2012 Distinct transcriptional programs mediated by the ligand-dependent full-length androgen receptor and its splice variants in castration-resistant prostate cancer. Cancer Res 72: 3457-34562.

13. Jagla M, Feve M, Kessler P, et al, 2007 A splicing variant of the androgen receptor detected in a metastatic prostate cancer exhibits exclusively cytoplasmic actions. Endocrinology 148: 4334-4343.

14. Yang X, Guo Z, Sun F, et al, 2011 Novel membraneassociated androgen receptor splice variant potentiates proliferative and survival responses in prostate cancer cells. J Biol Chem 286: 36152-36160.

15. Tsuei DJ, Lee PH, Peng HY, et al, 2011 Male germ cellspecific RNA binding protein RBMY: a new oncogene explaining male predominance in liver cancer. PLoS One 6: e26948.

16. Wu ZY, Chen K, Haendler B, McDonald TV, Bian JS 2008 Stimulation of N-terminal truncated isoform of androgen receptor stabilizes human ether-a-go-gorelated gene-encoded potassium channel protein via 
activation of extracellular signal regulated kinase 1/2. Endocrinology 149: 5061-5069.

17. Hornberg E, Ylitalo EB, Crnalic S, et al, 2011 Expression of androgen receptor splice variants in prostate cancer bone metastases is associated with castration-resistance and short survival. PLoS One 6: e19059.

18. Zhao H, Coram MA, Nolley R, Reese SW, Young SR, Peehl DM, 2012 Transcript levels of androgen receptor variant AR-V1 or AR-V7 do not predict rec urrence in patients with prostate cancer at indeterminate risk for progression. J Urol 188: 2158-2164.

19. Steinkamp MP, O’Mahony OA, Brogley M, et al, 2009 Treatment-dependent androgen receptor mutations in prostate cancer exploit multiple mechanisms to evade therapy. Cancer Res 69: 4434-4442.

20. Ozanne DM, Brady ME, Cook S, Gaughan L, Neal DE, Robson CN, 2000 Androgen receptor nuclear translocation is facilitated by the f-actin cross-linking protein filamin. Mol Endocrinol 14: 1618-1626.

21. Edwards J, Bartlett JM, 2005 The androgen receptor and signal-transduction pathways in hormone-refractory prostate cancer. Part 1: Modifications to the androgen receptor. BJU Int 95: 1320-1326.

22. Green SM, Mostaghel EA, Nelson PS, 2012 Androgen action and metabolism in prostate cancer. Mol Cell Endocrinol 360: 3-13.

23. Cato AC, Henderson D, Ponta H, 1987 The hormone response element of the mouse mammary tumour virus DNA mediates the progestin and androgen induction of transcription in the proviral long terminal repeat region. EMBO J 6: 363-368.

24. Ham J, Thomson A, Needham M, Webb P, Parker M 1988 Characterization of response elements for androgens, glucocorticoids and progestins in mouse mammary tumour virus. Nucleic Acids Res 16: 5263-5276.

25. Verrijdt G, Schoenmakers E, Haelens A, et al, 2000 Change of specificity mutations in androgen-selective enhancers. Evidence for a role of differential DNA binding by the androgen receptor. J Biol Chem 275: 12298-12305.

26. Lonergan PE, Tindall DJ, 2011 Androgen receptor signaling in prostate cancer development and progression. J Carcinog 10: 20.

27. Armen TA, Gay CV, 2000 Simultaneous detection and functional response of testosterone and estradiol receptors in osteoblast plasma membranes. J Cell Biochem 79: 620-627.

28. Benten WP, Lieberherr M, Giese G, et al, 1999 Functional testosterone receptors in plasma membranes of T cells. Faseb J 13: 123-133.

29. Benten WP, Lieberherr M, Sekeris CE, Wunderlich F 1997 Testosterone induces Ca2+ influx via non-genomic surface receptors in activated T cells. FEBS Lett 407: 211-214.

30. Benten WP, Lieberherr M, Stamm O, Wrehlke C, Guo Z, Wunderlich F, 1999 Testosterone signaling through internalizable surface receptors in androgen receptorfree macrophages. Mol Biol Cell 10: 3113-3123.

31. Felden F, Leheup B, Fremont S, et al, 1992 The plasma membrane of epididymal epithelial cells has a specific receptor which binds to androgen-binding protein and sex steroid- binding protein. J Steroid Biochem Mol Biol 42: 279-285.

32. Lieberherr M, Grosse B, 1994 Androgens increase intracellular calcium concentration and inositol 1,4,5-trisphosphate and diacylglycerol formation via a pertussis toxin-sensitive G-protein. J Biol Chem 269: 7217-7223.

33. Kampa M, Nifli AP, Charalampopoulos I, et al, 2005 Opposing effects of estradiol- and testosterone-membrane binding sites on T47D breast cancer cell apoptosis. Exp Cell Res 307: 41-51.

34. Kampa M, Papakonstanti EA, Hatzoglou A, Stathopoulos EN, Stournaras C, Castanas E, 2002 The human prostate cancer cell line LNCaP bears functional membrane testosterone receptors that increase PSA secretion and modify actin cytoskeleton. Faseb J 16: 1429-1431.

35. Stathopoulos EN, Dambaki C, Kampa M, et al, 2003 Membrane androgen binding sites are preferentially expressed in human prostate carcinoma cells. BMC Clin Pathol 3: 1.

36. Dambaki C, Kogia C, Kampa M, et al, 2005 Membrane testosterone binding sites in prostate carcinoma as a potential new marker and therapeutic target: study in paraffin tissue sections. BMC Cancer 5: 148.

37. Hatzoglou A, Kampa M, Kogia C, et al, 2005 Membrane androgen receptor activation induces apoptotic regression of human prostate cancer cells in vitro and in vivo. J Clin Endocrinol Metab 90: 893-903.

38. Kampa M, Castanas E, 2006 Membrane steroid receptor signaling in normal and neoplastic cells. Mol Cell Endocrinol 246: 76-82.

39. Kampa M, Pelekanou V, Castanas E, 2008 Membraneinitiated steroid action in breast and prostate cancer. Steroids 73: 953-960.

40. Levin ER, 2008 Rapid signaling by steroid receptors. Am J Physiol Regul Integr Comp Physiol 295: R14251430 .

41. Notas G, Pelekanou V, Castanas E, Kampa M, 2010 Conjugated and non-conjugated androgens differentially modulate specific early gene transcription in breast cancer in a cell-specific manner. Steroids 75: 611-618.

42. Kampa M, Kogia C, Theodoropoulos PA, et al, 2006 Activation of membrane androgen receptors potentiates the antiproliferative effects of paclitaxel on human prostate cancer cells. Mol Cancer Ther 5: 1342-1351.

43. Pedram A, Razandi M, Sainson RC, Kim JK, Hughes CC, Levin ER, 2007 A conserved mechanism for steroid receptor translocation to the plasma membrane. J Biol Chem 282: 22278-22288.

44. Martinez HD, Jasavala RJ, Hinkson I, et al, 2008 RNA editing of androgen receptor gene transcripts in prostate cancer cells. J Biol Chem 283: 29938-29949. 
45. Lee SO, Tian J, Huang CK, et al, 2012 Suppressor role of androgen receptor in proliferation of prostate basal epithelial and progenitor cells. J Endocrinol 213: 173182.

46. Li Y, Li CX, Ye H, et al, 2008 Decrease in stromal androgen receptor associates with androgen-independent disease and promotes prostate cancer cell proliferation and invasion. J Cell Mol Med 12: 2790-2798.

47. Lai KP, Yamashita S, Huang CK, Yeh S, Chang C, 2012 Loss of stromal androgen receptor leads to suppressed prostate tumourigenesis via modulation of pro-inflammatory cytokines/chemokines. EMBO Mol Med 4: 791-807.

48. Ricke EA, Williams K, Lee YF, et al, 2012 Androgen hormone action in prostatic carcinogenesis: stromal androgen receptors mediate prostate cancer progression, malignant transformation and metastasis. Carcinogenesis 33: 1391-1398.

49. Labrie F 2011 Blockade of testicular and adrenal androgens in prostate cancer treatment. Nat Rev Urol 8: 73-85.

50. Mottet N, Bellmunt J, Bolla M, et al, 2011 EAU guidelines on prostate cancer. Part II: Treatment of advanced, relapsing, and castration-resistant prostate cancer. Eur Urol 59: 572-583.

51. Payne H, Mason M, 2011 Androgen deprivation therapy as adjuvant/neoadjuvant to radiotherapy for high-risk localised and locally advanced prostate cancer: recent developments. Br J Cancer 105: 1628-1634.

52. Ismail M, Ferroni M, Gomella LG, 2011 Androgen suppression strategies for prostate cancer: is there an ideal approach? Curr Urol Rep 12: 188-196.

53. Mostaghel EA, Nelson PS, 2008 Intracrine androgen metabolism in prostate cancer progression: mechanisms of castration resistance and therapeutic implications. Best Pract Res Clin Endocrinol Metab 22: 243-258.

54. Stanbrough M, Bubley GJ, Ross K, et al, 2006 Increased expression of genes converting adrenal androgens to testosterone in androgen-independent prostate cancer. Cancer Res 66: 2815-2825.

55. Ji Q, Chang L, Stanczyk FZ, Ookhtens M, Sherrod A, Stolz A, 2007 Impaired dihydrotestosterone catabolism in human prostate cancer: critical role of AKR1C2 as a pre-receptor regulator of androgen receptor signaling. Cancer Res 67: 1361-1369.

56. Attard G, Sarker D, Reid A, Molife R, Parker C, de Bono JS 2006 Improving the outcome of patients with castration-resistant prostate cancer through rational drug development. Br J Cancer 95: 767-774.

57. Ford OH, 3rd, Gregory CW, Kim D, Smitherman AB, Mohler JL, 2003 Androgen receptor gene amplification and protein expression in recurrent prostate cancer. $\mathrm{J}$ Urol 170: 1817-1821.

58. Taylor BS, Schultz N, Hieronymus H, et al, 2010 Integrative genomic profiling of human prostate cancer. Cancer Cell 18: 11-22.
59. Edwards J, Krishna NS, Grigor KM, Bartlett JM, 2003 Androgen receptor gene amplification and protein expression in hormone refractory prostate cancer. Br J Cancer 89: 552-556.

60. Sharma A, Yeow WS, Ertel A, et al, 2010 The retinoblastoma tumor suppressor controls androgen signaling and human prostate cancer progression. J Clin Invest 120: 4478-4492.

61. Hara T, Miyazaki J, Araki H, et al, 2003 Novel mutations of androgen receptor: a possible mechanism of bicalutamide withdrawal syndrome. Cancer Res 63: 149-153.

62. Taplin ME, Rajeshkumar B, Halabi S, et al, 2003 Androgen receptor mutations in androgen-independent prostate cancer: Cancer and Leukemia Group B Study 9663. J Clin Oncol 21: 2673-2678.

63. Yoshida T, Kinoshita H, Segawa T, et al, 2005 Antiandrogen bicalutamide promotes tumor growth in a novel androgen-dependent prostate cancer xenograft model derived from a bicalutamide-treated patient. Cancer Res 65: 9611-9616.

64. Taplin ME, 2007 Drug insight: role of the androgen receptor in the development and progression of prostate cancer. Nat Clin Pract Oncol 4: 236-244.

65. Wu JD, Haugk K, Woodke L, Nelson P, Coleman I, Plymate SR, 2006 Interaction of IGF signaling and the androgen receptor in prostate cancer progression. J Cell Biochem 99: 392-401.

66. Gregory CW, Fei X, Ponguta LA, et al, 2004 Epidermal growth factor increases coactivation of the androgen receptor in recurrent prostate cancer. J Biol Chem 279: 7119-7130.

67. Schweizer L, Rizzo CA, Spires TE, et al, 2008 The androgen receptor can signal through Wnt/beta-Catenin in prostate cancer cells as an adaptation mechanism to castration levels of androgens. BMC Cell Biol 9: 4.

68. Bakin RE, Gioeli D, Bissonette EA, Weber MJ, 2003 Attenuation of Ras signaling restores androgen sensitivity to hormone-refractory C4-2 prostate cancer cells. Cancer Res 63: 1975-1980.

69. Bakin RE, Gioeli D, Sikes RA, Bissonette EA, Weber MJ, 2003 Constitutive activation of the Ras/mitogenactivated protein kinase signaling pathway promotes androgen hypersensitivity in LNCaP prostate cancer cells. Cancer Res 63: 1981-1989.

70. Liu Y, Karaca M, Zhang Z, Gioeli D, Earp HS, Whang YE, 2010 Dasatinib inhibits site-specific tyrosine phosphorylation of androgen receptor by Ack1 and Src kinases. Oncogene 29: 3208-3216.

71. Chen S, Xu Y, Yuan X, Bubley GJ, Balk SP, 2006 Androgen receptor phosphorylation and stabilization in prostate cancer by cyclin-dependent kinase 1 . Proc Natl Acad Sci U S A 103: 15969-15974.

72. Lin HK, Hu YC, Yang L, et al, 2003 Suppression versus induction of androgen receptor functions by the phosphatidylinositol 3-kinase/Akt pathway in prostate 
cancer LNCaP cells with different passage numbers. J Biol Chem 278: 50902-50907.

73. Ueda T, Bruchovsky N, Sadar MD, 2002 Activation of the androgen receptor N-terminal domain by interleukin- 6 via MAPK and STAT3 signal transduction pathways. J Biol Chem 277: 7076-7085.

74. Aaronson DS, Muller M, Neves SR, et al, 2007 An androgen-IL-6-Stat3 autocrine loop re-routes EGF signal in prostate cancer cells. Mol Cell Endocrinol 270: 50-56.

75. McDonnell TJ, Troncoso P, Brisbay SM, et al, 1992 Expression of the protooncogene bcl-2 in the prostate and its association with emergence of androgen-independent prostate cancer. Cancer Res 52: 6940-6944.

76. Oldridge EE, Pellacani D, Collins AT, Maitland NJ, 2012 Prostate cancer stem cells: are they androgenresponsive? Mol Cell Endocrinol 360: 14-24.

77. Hsing AW, Chu LW, Stanczyk FZ, 2008 Androgen and prostate cancer: is the hypothesis dead? Cancer Epidemiol Biomarkers Prev 17: 2525-2530.

78. Kirby M, Hirst C, Crawford ED, 2011 Characterising the castration-resistant prostate cancer population: a systematic review. Int J Clin Pract 65: 1180-1192.

79. Galsky MD, Small AC, Tsao CK, Oh WK, 2012 Clinical development of novel therapeutics for castrationresistant prostate cancer: historic challenges and recent successes. CA Cancer J Clin 62: 299-308.

80. Tran C, Ouk S, Clegg NJ, et al, 2009 Development of a second-generation antiandrogen for treatment of advanced prostate cancer. Science 324: 787-790.

81. Scher HI, Beer TM, Higano CS, et al, 2010 Antitumour activity of MDV3100 in castration-resistant prostate cancer: a phase 1-2 study. Lancet 375: 1437-1446.

82. Clegg NJ, Wongvipat J, Joseph JD, et al, 2012 ARN509: a novel antiandrogen for prostate cancer treatment. Cancer Res 72: 1494-1503.

83. Handratta VD, Vasaitis TS, Njar VC, et al, 2005 Novel C17-heteroaryl steroidal CYP17 inhibitors/antiandrogens: synthesis, in vitro biological activity, pharmacokinetics, and antitumor activity in the LAPC4 human prostate cancer xenograft model. J Med Chem 48: 2972-2984.

84. Schayowitz A, Sabnis G, Njar VC, Brodie AM, 2008 Synergistic effect of a novel antiandrogen, VN/124-1, and signal transduction inhibitors in prostate cancer progression to hormone independence in vitro. Mol Cancer Ther 7: 121-132.

85. Zoubeidi A, Zardan A, Beraldi E, et al, 2007 Cooperative interactions between androgen receptor (AR) and heatshock protein 27 facilitate AR transcriptional activity. Cancer Res 67: 10455-10465.
86. Bergerat JP, Ceraline J, 2009 Pleiotropic functional properties of androgen receptor mutants in prostate cancer. Hum Mutat 30: 145-157.

87. Andersen RJ, Mawji NR, Wang J, et al, 2010 Regression of castrate-recurrent prostate cancer by a small-molecule inhibitor of the amino-terminus domain of the androgen receptor. Cancer Cell 17: 535-546.

88. Koutsilieris M, Dimopoulos T, Milathianakis C, et al, 2007 Combination of somatostatin analogues and dexamethasone (anti-survival-factor concept) with luteinizing hormone-releasing hormone in androgen ablation-refractory prostate cancer with bone metastasis. BJU Int 100 Suppl 2: 60-62.

89. Koutsilieris M, Mitsiades C, Sourla A, 2000 Insulin-like growth factor I and urokinase-type plasminogen activator bioregulation system as a survival mechanism of prostate cancer cells in osteoblastic metastases: development of anti-survival factor therapy for hormone-refractory prostate cancer. Mol Med 6: 251-267.

90. Leibowitz RL, Dorff TB, Tucker S, Symanowski J, Vogelzang NJ, 2010 Testosterone replacement in prostate cancer survivors with hypogonadal symptoms. BJU Int 105: 1397-1401.

91. Morris MJ, Huang D, Kelly WK, et al, 2009 Phase 1 trial of high-dose exogenous testosterone in patients with castration-resistant metastatic prostate cancer. Eur Urol 56: 237-244.

92. Szmulewitz R, Mohile S, Posadas E, et al, 2009 A randomized phase 1 study of testosterone replacement for patients with low-risk castration-resistant prostate cancer. Eur Urol 56: 97-103.

93. Kampa M, Theodoropoulou K, Mavromati F, et al, 2011 Novel oligomeric proanthocyanidin derivatives interact with membrane androgen sites and induce regression of hormone-independent prostate cancer. J Pharmacol Exp Ther 337: 24-32.

94. Bluemn EG, Nelson PS, 2012 The androgen/androgen receptor axis in prostate cancer. Curr Opin Oncol 24: 251-257.

95. Obertova Z, Brown C, Holmes M, Lawrenson R, 2012 Prostate cancer incidence and mortality in rural men--a systematic review of the literature. Rural Remote Health 12: 2039.

96. Ryan CJ, Tindall DJ, 2011 Androgen receptor rediscovered: the new biology and targeting the androgen receptor therapeutically. J Clin Oncol 29: 3651-3658.

97. Qiu YQ, Leuschner I, Braun PM, 2008 Androgen receptor expression in clinically localized prostate cancer: immunohistochemistry study and literature review. Asian J Androl 10: 855-863. 